\title{
Is allergic rhinitis related to migraine disability in adults?
}

\author{
Rinite alérgica está relacionada à incapacidade da migrânea em adultos? \\ Cassiano Mateus FORCELINI', Ricardo Tobias Sartori GRADASCHI', Gabriel Augusto TONIN', Douglas Filipi \\ BIANCHI', Gustavo Korssak GONÇALVES'1, Gustavo HIRT', Arnaldo Carlos PORTO NETO'
}

\begin{abstract}
Migraine is a chronic condition with complex pathophysiology. Although immunologic disturbances have been linked to migraine, only few attempts have been made to assess the possibility of allergic rhinitis as a worsening factor of migraine in adults. Objective: This survey aimed to compare migraine disability between adult migraineurs with and without current allergic rhinitis. Methods: This cross-sectional study comprised 118 adult migraineurs who were consecutively assisted at an outpatient clinic. After ordinary neurological evaluation, participants were evaluated for headache disability using the Migraine Disability Assessment (MIDAS). The presence of current allergic rhinitis, allergic rhinoconjunctivitis and seasonal allergic rhinitis was scored for each participant according to the International Study of Asthma and Allergies in questionnaire. Results: There was no significant difference between the MIDAS scores of those with current allergic rhinitis, allergic rhinoconjunctivitis, or seasonal allergic rhinitis and nonatopic migraineurs. The disability caused by allergic symptoms also did not influence the MIDAS scores of patients with allergic rhinitis. The frequency of headache days during the last three months was higher in the subset of patients without allergic rhinitis (median and interquartile range 12 [8-19.2] vs. 8 [4-14]; $p=0.03$ ). Conclusions: Our results suggest that current allergic rhinitis, allergic rhinoconjunctivitis, and seasonal allergic rhinitis are not related to headache disability in adults with episodic migraine.
\end{abstract}

Keywords: Migraine disorders; headache; rhinitis, allergic; immune system.

\section{RESUMO}

A migrânea é uma condição dolorosa crônica com fisiopatologia complexa. Apesar de disfunções imunológicas já terem sido ligadas à migrânea, poucas foram as tentativas, na literatura, de se avaliar a possibilidade da rinite alérgica como um fator agravante da migrânea em adultos, tornando a questão ainda não esclarecida. Objetivo: Esta pesquisa visou comparar a incapacidade da migrânea em adultos com e sem rinite alérgica. Métodos: Este estudo transversal incluiu 118 adultos com migrânea consecutivamente atendidos em uma clínica ambulatorial. Após o exame neurológico usual, os participantes foram avaliados com relação à incapacidade gerada pela cefaleia com o Migraine Disability Assessment (MIDAS), assim como para a presença atual de rinite alérgica, rinoconjuntivite alérgica e rinite alérgica sazonal de acordo com o questionário do International Study of Asthma and Allergies in Childhood (ISAAC). Resultados: Não houve diferença nos escores do MIDAS entre migranosos com e sem alérgica, rinoconjuntivite alérgica e rinite alérgica sazonal. A incapacidade causada pelos sintomas alérgicos também não influenciou os escores do MIDAS dos pacientes com rinite alérgica. A frequência de dias com cefaleia durante os últimos 3 meses foi maior no subgrupo de pacientes sem rinite alérgica (mediana e intervalo interquartil 12 [819,2] vs. 8 [4-14]; $p=0$,03). Conclusões: Os resultados sugerem que rinite alérgica, rinoconjuntivite alérgica e rinite alérgica sazonal não estão relacionadas à incapacidade por cefaleia em pacientes adultos com migrânea episódica.

Palavras-chave: Transtornos da enxaqueca; cefaleia; rinite alérgica; sistema imunitário.

Migraine is a chronic condition that affects $15.8 \%$ of the Brazilian population, leading to a remarkable impact on the quality of life of patients, especially women ${ }^{1}$. Complications such as chronic migraine, status migrainosus and eventually stroke may also occur ${ }^{23}$. Migraine is not the most common primary headache; however, it is the leading cause of headache disability, especially among those who seek emergency assistance ${ }^{4}$.

The pathophysiology of migraine is complex. Inherited predisposition and dysfunction of the nociceptive trigeminal system $^{5}$ seem to play major roles in the source of migraine manifestations, while cortical spreading depression is related

\footnotetext{
${ }^{1}$ Universidade de Passo Fundo, Faculdade de Medicina, Passo Fundo, RS, Brasil.

Cassiano Mateus Forcelini (iD https://orcid.org/0000-0001-9614-1139; Ricardo Tobias Sartori Gradaschi iD https://orcid.org/0000-0003-1078-8447; Gabriel Augusto Tonin (iD) https://orcid.org/0000-0003-4792-8917; Douglas Filipi Bianchi iD https://orcid.org/0000-0003-3980-0155; Gustavo Korssak Gonçalves (iD) https://orcid.org/0000-0002-4904-9716; Gustavo Hirt iD https://orcid.org/0000-0002-3174-6070;Arnaldo Carlos Porto Neto iD https://orcid.org/0000-0002-1829-5359

Correspondence: Cassiano Mateus Forcelini; R. Teixeira Soares, 817 - 99010-080 Passo Fundo RS, Brasil; E-mail: cmforcelini@gmail.com
}

Conflict of interest: There is no conflict of interest to declare.

Received 13 August 2018; Received in final form 28 February 2019; Accepted 07 April 2019. 
to migraine aura ${ }^{6}$. Psychiatric comorbidities and medication-overuse can strongly predispose the patient to migraine aggravation ${ }^{7,8,9}$. Other conditions, such as atopic diseases ${ }^{10-14}$, have previously been linked to migraine, although not consistently.

Allergic rhinitis is an atopic condition affecting the upper airways that has a high prevalence in Brazil ${ }^{15,16}$ and causes a variable impact on patients' quality of life based on the intensity of symptoms ${ }^{17}$. There is evidence suggesting an increase in its frequency over the last decades ${ }^{15,18}$, possibly due to environmental pollution ${ }^{18}$. The core manifestations of allergic rhinitis or rhinoconjunctivitis are nasal congestion and discharge, sneezing, and eye itching and watering, symptoms that share a common neural pathway, in terms of sensitive trigeminal transmission, with migraine. Such rich inflammatory processes that take place in allergic rhinitis could theoretically predispose the patient to migraine worsening, not only through cephalic nociceptive pathways, but also by triggering an immune response not necessarily restricted to the head. For example, allergic sensitization measured by serum immunoglobulin E (IgE) has already been linked to aggravated migraine in adults ${ }^{19}$. Putative neurogenic inflammation ${ }^{20}$ could also be a mechanism of migraine triggering by immune response. However, this type of model is not currently considered relevant in migraine pathophysiology ${ }^{21}$.

In this setting, this survey aimed to compare the migraine disability, - measured by a traditional instrument, the Migraine Disability Assessment (MIDAS) ${ }^{22}$ - between adult migraineurs with and without current allergic rhinitis, allergic rhinoconjunctivitis and seasonal allergic rhinitis, to investigate whether atopic diseases affecting the head could be related the impact of headache on patients' lives.

\section{METHODS}

A sample of 118 adult patients with migraine with or without aura - diagnosed according to the International Classification of Headache Disorders, $3{ }^{\text {rd }}$ edition (beta version $)^{23}$ - was included in this cross-sectional study. Patients were consecutively assisted at the Instituto de Neurologia e Neurocirurgia, an outpatient neurological clinic of Passo Fundo, RS, Brazil, from November 2016 to April 2017. After the ordinary neurological evaluation, the patients were invited to participate in the study and gave their written consent. No patient declined participation during the period of this research, which was conducted in accordance with the Declaration of Helsinki and was approved by the Ethical Committee of Universidade de Passo Fundo on October 18, 2016 (report number 1.779.204). Sample size was estimated with the aid of software WinPepi version 11.50 (J. H. Abramson) based on previous results from Rosario and Pinto who correlated allergic sensitization characterized by high blood levels of IgE with greater disability due to headache in 100 migraineurs $^{19}$.

Demographic and clinical data focused on migraine were obtained from the interviews conducted just after neurological evaluation, including the number of headache days per month during the previous three months and the average severity of headache based on a visual analog scale for pain $(0-10)^{24}$. Afterwards, patients were given the validated Portuguese version of the International Study of Asthma and Allergies in Childhood (ISAAC) for perennial and seasonal allergic rhinitis questionnaire ${ }^{25}$, and the MIDAS translated into Portuguese ${ }^{26}$. Although the ISAAC questionnaire was originally created for evaluating children and adolescents, several studies worldwide have employed it with adults in the last decade ${ }^{27}$. Participants diagnosed with asthma were excluded.

According to the ISAAC questionnaire, current allergic rhinitis was defined as having had a runny, itchy or stuffy nose without a cold in the previous 12 months ${ }^{28}$. The presence of nasal symptoms associated with eye symptoms within the previous 12 months among those diagnosed with allergic rhinitis was considered to be allergic rhinoconjunctivitis $^{28}$. Finally, the presence of seasonal allergic rhinitis was established by a positive reply to the previous questions and to the modified, last question of the Portuguese version of the ISAAC questionnaire (Have you ever had allergic rhinitis related to pollen [during the spring]? $)^{25}$. The diagnoses of allergic rhinitis, allergic rhinoconjunctivitis and seasonal allergic rhinitis were not mutually exclusive. If present, the impact of these conditions on daily life was assessed by the following question of the ISAAC questionnaire (In the past 12 months, how much did this nose problem interfere with your daily activities?) with the possible answers (not at all; a little; a moderate amount; a lot). We defined "presence of disability due to allergic rhinitis" as any answer different than "not at all".

The MIDAS instrument is a five-item questionnaire developed to measure headache-related disability, providing a score (the higher the score, the worse the disability) that is the sum of the days in the previous three months that the patient had any kind of disability caused by migraine ${ }^{22}$.

\section{Statistical analysis}

Quantitative variables were presented as median and 25\%-75\% interquartile range (IQR) due to asymmetrical distribution. Categorical data were described as percentages. The Mann-Whitney U test was used to compare quantitative variables. The analyses were performed with the commercially available Statistical Package for the Social Sciences (SPSS) version 16.0 (SPSS Inc, Chicago, IL, USA) and GraphPad Prism version 5.00 (GraphPad Software Inc, San Diego, CA, USA). Statistical significance was assessed with a two-tailed p-value $<0.05$. 


\section{RESULTS}

Demographic and clinical characteristics of the sample are shown in Table 1. All participants were Caucasian, reflecting the local ethnic composition in south Brazil. Most were women, as expected for migraine sufferers, and young adults.

Table 2 shows the comparisons of quantitative variables between those migraineurs with or without current allergic rhinitis, allergic rhinoconjunctivitis, and seasonal allergic rhinitis. We also performed an analysis of the impact of the disability caused by allergic symptoms on the MIDAS scores from patients with atopy. Patients without any disability due to the allergic symptoms had a median MIDAS score of 27 [13.7-45.5], while those who had some disability had a median score of 32 [12-60] $(\mathrm{p}=0.49)$.

\section{DISCUSSION}

The association between migraine and atopic disease involving the upper airways has been investigated extensively in migraine research. Several studies revealed a higherthan-expected prevalence of migraine among patients with allergic rhinitis ${ }^{10,13}$. An increased frequency of the latter in migraineurs during childhood has also been reported ${ }^{11}$. However, few studies have considered the possibility of aggravation of migraine related to nasal atopy, even though these conditions may share common neural pathways and mediators ${ }^{14}$.

We defined the score from the MIDAS questionnaire a reliable instrument for assessing the disability caused by headache - as our primary outcome in terms of comparing migraineurs with or without allergic rhinitis, because of the objectivity of measurement and the availability of a translated Portuguese version. In our sample of adult patients, there was no difference between the MIDAS scores of those with current allergic rhinitis, allergic rhinoconjunctivitis, or seasonal allergic rhinitis and nonatopic migraineurs. The disability caused by allergic symptoms also did not influence the MIDAS scores from patients with allergic rhinitis, who represented roughly $50 \%$ to $60 \%$ of the sample. These findings suggest that allergic rhinitis was not an enhancer of migraine disability in our sample of young adult participants consecutively assisted in a general neurological outpatient clinic. Instead, the frequency of headache days during the three months prior to completing the questionnaire was even higher in the subset of patients without pure allergic rhinitis.

However, this finding may not be applicable to patients with more severe migraine. For example, a large survey of thousands of severe headache patients from the USA found that the presence of rhinitis was associated with headache frequency, while headache-related disability measured by the MIDAS was linked to rhinitis after adjusting for sociodemographic features ${ }^{29}$. Nevertheless, the proportion of participants who did not respond to the research questionnaire was remarkably high (40\%), raising the possibility of a selection bias that may limit the generalization of these results to a broader population of headache patients.

Other factors that may interfere with the relationship between allergic rhinitis and migraine are age, degree of allergic sensitization, and administration of immunotherapy ${ }^{10}$. Martin et al. ${ }^{10}$ evaluated a sample of headache patients from an allergy clinic and found that those up to 45 years of age had an enhancing effect of allergic sensitization on migraine disability and frequency, whereas immunotherapy had a decreasing effect. However, no comparison was made in migraineurs without allergic rhinitis.

Our study has some limitations that must be addressed. Firstly, the cross-sectional design is strong for generating hypotheses, but not the most powerful design for

Table 1. Demographic and clinical characteristics of the patients $(n=118)$. Qualitative variables are presented as absolute count and percentage, while quantitative data are shown as median and interquartile range.

\begin{tabular}{|c|c|c|c|}
\hline \multirow[b]{2}{*}{ Characteristics } & \multicolumn{3}{|c|}{ Results } \\
\hline & $\begin{array}{l}\text { Absolute count and } \\
\text { percentage }\end{array}$ & Median & Interquartile range \\
\hline Female & $99(84 \%)$ & & \\
\hline Male & $19(16 \%)$ & & \\
\hline White & $118(100 \%)$ & & \\
\hline Age (years) & & 33 & $26.7-43.2$ \\
\hline Body Mass Index $\left(\mathrm{kg} / \mathrm{m}^{2}\right)$ & & 22.6 & $21.3-25.2$ \\
\hline Migraine with aura & $19(16 \%)$ & & \\
\hline Migraine without aura & $99(84 \%)$ & & \\
\hline Days with headache (per month) & & 10 & $5-15$ \\
\hline Severity of headache (on visual analogical scale) & & 8 & $6-8$ \\
\hline MIDAS score & & 27.5 & $12.7-56.2$ \\
\hline Allergic rhinitis & $78(66 \%)$ & & \\
\hline Allergic rhinoconjunctivitis & $59(50 \%)$ & & \\
\hline Seasonal allergic rhinitis & $56(47 \%)$ & & \\
\hline
\end{tabular}


Table 2. Comparisons of age, body mass index, number of days with headache per month, severity of headache on a visual analogical scale and MIDAS score between migraineurs $(n=118)$ with or without allergic rhinitis, allergic rhinoconjunctivitis and seasonal allergic rhinitis [median and interquartile range]†.

\begin{tabular}{|c|c|c|c|c|c|}
\hline \multirow{2}{*}{ Variable } & \multicolumn{2}{|c|}{ Presence of allergic rhinitis $(n=78)$} & \multicolumn{2}{|c|}{ Absence of allergic rhinitis $(n=40)$} & \multirow[t]{2}{*}{ p-value } \\
\hline & Median & Interquartile range & Median & Interquartile range & \\
\hline Age (years) & 33 & $26-41.2$ & 35 & $28-48.7$ & 0.28 \\
\hline Body Mass Index $\left(\mathrm{kg} / \mathrm{m}^{2}\right)$ & 23 & $21.4-25.4$ & 22.1 & $20.7-24.8$ & 0.14 \\
\hline Days with headache (per month) & 8 & $4-14$ & 12 & $8-19.2$ & 0.03 \\
\hline Severity on visual analogical scale & 8 & $6-8$ & 8 & $7-8$ & 0.83 \\
\hline \multirow[t]{3}{*}{ MIDAS score } & 26 & $12-57.7$ & 30 & $17.2--49.2$ & 0.38 \\
\hline & \multicolumn{2}{|c|}{$\begin{array}{c}\text { Presence of allergic } \\
\text { rhinoconjunctivitis }(n=59)\end{array}$} & \multicolumn{2}{|c|}{$\begin{array}{c}\text { Absence of allergic } \\
\text { rhinoconjunctivitis }(n=59)\end{array}$} & $\mathrm{p}$-value \\
\hline & Median & Interquartile range & Median & Interquartile range & \\
\hline Age (years) & 33 & $27.7-40.2$ & 34 & $26-47.7$ & 0.44 \\
\hline Body Mass Index $\left(\mathrm{kg} / \mathrm{m}^{2}\right)$ & 23.2 & $21.4-26$ & 22.2 & $20.8-24$ & 0.06 \\
\hline Days with headache (per month) & 8 & $4-14$ & 10 & $6-15.5$ & 0.11 \\
\hline Severity on visual analogical scale & 7.2 & $6-8$ & 8 & $6.5-8$ & 0.43 \\
\hline \multirow[t]{3}{*}{ MIDAS score } & 23 & $10.2-59.2$ & 30 & $18-50$ & 0.19 \\
\hline & \multicolumn{2}{|c|}{$\begin{array}{l}\text { Presence of seasonal allergic rhinitis } \\
\qquad(n=57)\end{array}$} & \multicolumn{2}{|c|}{$\begin{array}{l}\text { Absence of seasonal allergic rhinitis } \\
\qquad(n=61)\end{array}$} & $\mathrm{p}$-value \\
\hline & Median & Interquartile range & Median & Interquartile range & \\
\hline Age (years) & 33 & $26-39$ & 35 & $28-47.5$ & 0.44 \\
\hline Body Mass Index $\left(\mathrm{kg} / \mathrm{m}^{2}\right)$ & 23.2 & $21.5-26$ & 22.2 & $20.8-24.2$ & 0.05 \\
\hline Days with headache (per month) & 8 & $5-14.7$ & 10 & $5.7-15$ & 0.58 \\
\hline Severity on visual analogical scale & 7.5 & $6-8$ & 8 & $6.7-8$ & 0.56 \\
\hline MIDAS score & 30 & $12-57.5$ & 27 & $16-50$ & 0.93 \\
\hline
\end{tabular}

MIDAS: Migraine disability assessment; †The Mann-Whitney $U$ test was employed for comparisons.

hypothesis-testing. Nonetheless, there is a lack of more powerful studies that compare episodic migraine adults with and without allergic rhinitis. Therefore, this report of a whole series of more than 100 consecutive outpatients (with no drop outs) provides important initial evidence that needs to be confirmed or refuted in future studies.

Secondly, the sample size was not large, which could obscure a potential enhancing effect of rhinitis on migraine disability. No trend toward this direction emerged from our statistical analyses of a consecutive group of migraine sufferers, suggesting that allergic rhinitis is not related to the disability of episodic migraine in adults who seek medical advice because of headaches. However, this data may not reflect the profile of the general population, especially because our sample did not include chronic migraine patients, a subset that may be more prone to detrimental influences from other illnesses.

Finally, the present research only included adults. Children with allergic rhinitis have been found to have a higher incidence and subsequent risk of migraine $e^{30}$. The results from our exploratory investigation in adult migraine patients do not exclude the possibility of a major relationship in the pediatric population, which is not affected by the senility of the immune system, or the influence of sex hormones observed in adults, especially women.

Our results suggest that there is no correlation of allergic rhinitis with headache disability in adults with episodic migraine. However, this possibility should be assessed in other clinical scenarios, especially in chronic migraine patients and in the pediatric population.

\section{References}

1. Queiroz LP, Silva Júnior AA. The prevalence and impact of headache in Brazil. Headache. 2015 Feb;55 Suppl 1:32-8. https://doi. org/10.1111/head.12511

2. Diener HC, Solbach K, Holle D, Gaul C. Integrated care for chronic migraine patients: epidemiology, burden, diagnosis and treatment options. Clin Med (Lond). 2015 Aug;15(4):344-50. https://doi. org/10.7861/clinmedicine.15-4-344

3. Sacco S, Ricci S, Carolei A. Migraine and vascular diseases: a review of the evidence and potential implications for management. Cephalalgia. 2012 Jul;32(10):785-95. https://doi. org/10.1177/0333102412451361
4. Burch RC, Loder S, Loder E, Smitherman TA. The prevalence and burden of migraine and severe headache in the United States: updated statistics from government health surveillance studies. Headache. 2015 Jan;55(1):21-34. https://doi.org/10.1111/head.12482

5. Akerman S, Romero-Reyes M. Insights into the pharmacological targeting of the trigeminocervical complex in the context of treatments of migraine. Expert Rev Neurother. 2013 Sep;13(9):104159. https://doi.org/10.1586/14737175.2013.827472

6. Charles AC, Baca SM. Cortical spreading depression and migraine. Nat Rev Neurol. 2013 Nov;9(11):637-44. https://doi.org/10.1038/ nrneurol.2013.192 
Seng EK, Seng CD. Understanding migraine and psychiatric comorbidity. Curr Opin Neurol. 2016 Jun;29(3):309-13. https://doi. org/10.1097/WC0.0000000000000309

8. Bellini B, Arruda M, Cescut A, Saulle C, Persico A, Carotenuto M, et al. Headache and comorbidity in children and adolescents. J Headache Pain. 2013 Sep;14(1):79. https://doi.org/10.1186/1129-2377-14-79

9. Cupini LM, Calabresi P. Medication-overuse headache: pathophysiological insights. J Headache Pain. 2005 Sep;6(4):199202. https://doi.org/10.1007/s10194-005-0184-z

10. Martin VT, Taylor F, Gebhardt B, Tomaszewski M, Ellison JS, Martin GV, et al. Allergy and immunotherapy: are they related to migraine headache? Headache. 2011 Jan;51(1):8-20. https://doi.org/10.1111/ j.1526-4610.2010.01792.x

11. Muñoz-Jareño N, Fernández-Mayoralas DM, Martínez-Cervell C, Campos-Castelló J. [Relationship between migraine and atopy in childhood: a retrospective case-control study]. Rev Neurol. 2011;53(12):713-20. Spanish.

12. Ozge A, Ozge C, Oztürk C, Kaleagasi H, Ozcan M, Yalçinkaya DE, et al. The relationship between migraine and atopic disordersthe contribution of pulmonary function tests and immunological screening. Cephalalgia. 2006 Feb;26(2):172-9. https://doi. org/10.1111/j.1468-2982.2005.01021.x

13. Mortimer MJ, Kay J, Gawkrodger DJ, Jaron A, Barker DC. The prevalence of headache and migraine in atopic children: an epidemiological study in general practice. Headache. 1993 Sep;33(8):427-31. https://doi.org/10.1111/j.1526-4610.1993. hed3308427.x

14. Güvenç IA, Acar M, Muluk NB, Kucukcan NE, Cingi C. Is there an association between migraine and allergic rhinitis? Ear Nose Throat J. 2017 Jun;96(6):E18-23. https://doi. org/10.1177/014556131709600604

15. Wilmer FA, Maurici R, Nazário CA, Nazário KC, Pássaro PF, Piazza $\mathrm{HE}$, et al. Temporal trends in the prevalence of asthma and rhinoconjunctivitis in adolescents. Rev Saude Publica. 2015;49(0):49. https://doi.org/10.1590/S0034-8910.2015049005558

16. Luna MF, Fisher GB, Luna JR, Silva MG, Almeida PC, Chiesa D. Prevalence of rhinitis among 6 and 7 -year old students in Fortaleza. Rev Assoc Med Bras (1992). $2014 \mathrm{Jul} ; 60(4): 357-64$. https://doi. org/10.1590/1806-9282.60.04.0015

17. Roger A, Arcalá Campillo E, Torres MC, Millan C, Jáuregui I, Mohedano $\mathrm{E}$, et al. Reduced work/academic performance and quality of life in patients with allergic rhinitis and impact of allergen immunotherapy. Allergy Asthma Clin Immunol. 2016 Aug;12(1):40. https://doi. org/10.1186/s13223-016-0146-9

18. D'Amato G, Holgate ST, Pawankar R, Ledford DK, Cecchi L, Al-Ahmad $\mathrm{M}$, et al. Meteorological conditions, climate change, new emerging factors, and asthma and related allergic disorders. A statement of the World Allergy Organization. World Allergy Organ J. 2015 Jul;8(1):25. https://doi.org/10.1186/s40413-015-0073-0
19. Rosario D, Pinto G. Role of Gender and Serum Immunoglobulin E (IGE) levels on Severity of Migraine.J Clin Diagn Res. 2014 Feb;8(2):57-8. https://doi.org/10.7860/JCDR/2014/7516.4007

20. Malhotra R. Understanding migraine: potential role of neurogenic inflammation. Ann Indian Acad Neurol. 2016 Apr-Jun;19(2):175-82. https://doi.org/10.4103/0972-2327.182302

21. Goadsby PJ, Holland PR, Martins-Oliveira M, Hoffmann J, Schankin C, Akerman S. Pathophysiology of Migraine: A Disorder of Sensory Processing. Physiol Rev. 2017 Apr;97(2):553-622. https://doi. org/10.1152/physrev.00034.2015

22. Stewart WF, Lipton RB, Whyte J, Dowson A, Kolodner K, Liberman $J \mathrm{~N}$, et al. An international study to assess reliability of the Migraine Disability Assessment (MIDAS) score. Neurology. 1999 Sep;53(5):988-94. https://doi.org/10.1212/WNL.53.5.988

23. International Headache Society. The International Classification of Headache Disorders, 3rd edition (beta version). Cephalalgia. 2013;33(9):629-808. https://doi.org/10.1177/0333102413485658

24. Hawker GA, Mian S, Kendzerska T, French M. Measures of adult pain: Visual Analog Scale for Pain (VAS Pain), Numeric Rating Scale for Pain (NRS Pain), McGill Pain Questionnaire (MPQ), Short-Form McGill Pain Questionnaire (SF-MPQ), Chronic Pain Grade Scale (CPGS), Short Form-36 Bodily Pain Scale (SF-36 BPS), and Measure of Intermittent and Constant Osteoarthritis Pain (ICOAP). Arthritis Care Res (Hoboken). 2011 Nov;63(S11 Suppl 11):S240-52. https:// doi.org/10.1002/acr.20543

25. Esteves PC, Trippia SG, Rosario Filho NA, Caleffe LG. [Validation of ISAAC questionnaire for perennial and seasonal allergic rhinitis in Curitiba]. Rev Bras Alerg Imunopatol. 1999;22(4):106-13. Portuguese.

26. Fragoso YD. MIDAS (Migraine Disability Assessment): a valuable tool for work-site identification of migraine in workers in Brazil. Sao Paulo Med J. 2002 Jul;120(4):118-21. https://doi.org/10.1590/S151631802002000400006

27. Sonia T, Meriem M, Yacine O, Nozha BS, Nadia M, Bechir L, et al. Prevalence of asthma and rhinitis in a Tunisian population. Clin Respir J. 2018 Feb;12(2):608-15. https://doi.org/10.1111/crj.12570

28. Beasley R; The International Study of Asthma and Allergies in Childhood (ISAAC) Steering Committee. Worldwide variation in prevalence of symptoms of asthma, allergic rhinoconjunctivitis, and atopic eczema: ISAAC. Lancet. 1998 Apr;351(9111):1225-32. https:// doi.org/10.1016/S0140-6736(97)07302-9

29. Martin VT, Fanning KM, Serrano D, Buse DC, Reed ML, Bernstein JA, et al. Chronic rhinitis and its association with headache frequency and disability in persons with migraine: results of the American Migraine Prevalence and Prevention (AMPP) Study. Cephalalgia. 2014 Apr;34(5):336-48. https://doi.org/10.1177/0333102413512031

30. Wang IC, Tsai JD, Lin CL, Shen TC, Li TC, Wei CC. Allergic rhinitis and associated risk of migraine among children: a nationwide population-based cohort study. Int Forum Allergy Rhinol. 2016 Mar;6(3):322-7. https://doi.org/10.1002/alr.21654 